УДК 339.1

JEL Classification: L10, M21, M32,

http://doi.org/

\title{
IMPROVEMENT OF MARKETING STRATEGIC MANAGEMENT AT THE INDUSTRIAL ENTERPRISE
}

\begin{abstract}
Purpose. Development of theoretical foundations and development of methodological recommendations for the formation and improvement of marketing management strategies in industrial enterprises, taking into account the specifics of their industry affiliation.

Method. The study of the essence and components of strategic marketing management is based on the methods of systems analysis and synthesis. The analysis of the stages of formation of strategic marketing management at an industrial enterprise is carried out on the basis of structural and logical methods.

Results. The approaches of different scientific schools to the formation of concepts of strategic management of marketing activities are analyzed. It is found out that strategic management of marketing activity uses methods of development of the general strategy which is a basis of certain functional strategies (marketing, production, financial, personnel, innovative), and mechanisms of their realization for the purpose of achievement of conformity of mission, the purposes and internal potential of the enterprise. external environment. The directions of formation of marketing management strategy at the coal mining enterprise on the basis of the carried-out researches are substantiated: definition of mission, the purposes and tasks of marketing at all levels of marketing management; substantiation of the strategy of partnership interaction. The stages of formation of marketing management strategy at the coal mining enterprise are offered. On the basis of the collected quantitative and qualitative data, with the use of the information received at filling in of the questionnaire and the analytical information the SWOT-analysis of marketing activity of mine is carried out. Based on the generalization of the analysis, it is appropriate to propose a general sequence of interaction strategy using the allocation of the integrator as a sequence of stages of strategy planning in the supply and marketing channels based on marketing partnerships.
\end{abstract}

Scientific novelty. The stages of formation of marketing management strategy at an industrial enterprise are substantiated taking into account the specifics of its branch affiliation and strategy of interaction on the basis of allocation of the integrator enterprise and formation of marketing of partnership relations.

Practical significance. The obtained results of the research determine the general directions of improvement of marketing strategic management at the industrial enterprise by definition of strategy formation stages of marketing and marketing of partner relations.

Key words: marketing strategy, marketing management, principles of marketing management, functions of marketing strategic management, coal mining enterprise, corporate strategy. portfolio strategy, SWOT-analysis, partnership portfolio

Introduction. The current level of economic development of any industry, regardless of ownership and type of activity, requires a competent, highly professional, focused approach to addressing external and internal issues. Working in the context of globalization, companies need to develop a long-term strategy that will allow them to take into account the rapidly occurring changes in the environment. If before the company focused only on internal work, now it is forced to build a management system that would optimally adapt quickly to the dynamic environment.

Improving strategic management through the development of marketing activities of an industrial enterprise should be focused on the fact that the viability and level of efficiency of the enterprise is entirely dependent on how deeply its management is aware of the role of marketing in the development of modern industrial enterprise. Therefore, the problem of forming an effective marketing management strategy in the enterprise needs further consideration and solution.
In the event that economic changes occur constantly, the company in a market environment must: first, meet the requirements of customers to compete successfully, and secondly, to adapt to changes or anticipate them. They were identified by I. Ansoff [1], when he considered different levels of environmental turbulence and classified the relevant necessary reactions of the enterprise. According to him, today most companies are forced not only to adapt to changes in the environment, but also to develop a strategy to anticipate them. The choice of the direction of strategic development becomes important for the enterprise. The problem of development and implementation of enterprise development strategy is given more and more attention in modern economics. An important issue is the professional and effective provision of the company with effective marketing tools, which requires management to pay attention to the formation of marketing strategy for their effective use. The development of the strategy should be consistent with the possibilities of its use. 
Analysis of recent research and publications. The complexity and versatility of the field of strategic marketing management, as well as the variability and uncertainty of the global economic environment form an unlimited range of research, while existing modern theoretical and methodological principles and practical recommendations are increasing scientific interest in marketing strategic management.

The work of many scientists is devoted to the study of strategic management and marketing, the formation of marketing management strategies at different levels, their individual elements and aspects: I. Ansoff [1], M. Martynenko [2], S. Filippova [3], O. Kuzmin, O. Melnyk [4], O. Mogilevska [5], L. Shemaeva [6], O. Arefieva [7], V. Grinyova [8], J. Lambena, B. Karloff, H. Koboyasi, F Kotler, I. Kretov, D. Krombrugge, K. Lindy, S. Majaro, J. MacArthur, M. Mescona, T. Fujimoto, G. Shmalena Y. Yudanova, D. Aaker, K. Bowman, E. Golubkov, D. Jober, P. Doyle, P. Drucker, J. Day, J. Evans, M. McDonald, R. Fatkhutdinov [9] and others.

The process of strategic decision-making in an industrial enterprise directly depends on the impact of strategic changes in the environment, which contribute to increasing the efficiency of the enterprise. In crisis situations, a changing environment should create conditions for the survival of the enterprise by optimizing the use of resources, costs and mechanisms for adaptation to it. According to [15-18], the lack of strategic changes is unable to ensure the same efficiency of the enterprise in different operating conditions for a long time. The dynamic development and the need to reform Ukraine's economy have led to the formation of a new marketing approach to solving problems of industrial production management and promotion of goods and services.

Working in the context of globalization, the industrial enterprise needs not only to focus on its internal situation, but also to form a long-term strategy that allows to take into account changes in the environment. If before the company focused only on internal work, now it is forced to build a management system that would optimally adapt quickly to the dynamic environment. Marketing strategy acts as a rational, logical construction, guided by which the company expects to solve its marketing problems. It includes specific strategies for target markets, the marketing mix and the level of marketing costs. To implement the chosen strategy of the enterprise it is advisable to implement certain practical actions.

The problem of formation and implementation of marketing strategy in today's rapidly changing environment is quite relevant and needs further development, so a number of scientists give it paramount importance in the formation of the overall strategy of the industrial enterprise. Despite the fact that the essence and components of strategic management mechanisms are discussed in detail in $[10-12,2,13,14]$, among scientists there is no single point of view on the components and mechanisms of marketing management strategies in industrial enterprises, taking into account the specifics of their industry affiliation. However, the efficiency of further development of industrial enterprises depends on this factor.

The purpose of the article (problem statement). Without underestimating the significance and importance of theoretical, methodological and practical developments of leading scientists in the field of research, it is appropriate to note that they can not be universal and do not fully take into account the rapidly changing modern world market and economic environment. Thus, the aim of the article is to develop theoretical foundations and develop guidelines for the formation and improvement of marketing management strategies in industrial enterprises, taking into account the specifics of their industry affiliation. Theoretical and methodological basis of the study are the laws and principles of dialectical logic, the provisions of economic theory, the concepts of prominent scientists on the problems of strategic management of marketing activities of enterprises. Achieving this goal is ensured by the use of methods of system analysis, structural and logical methods in the study of the essence of strategic marketing management and its tools, structural and logical methods - in determining the stages of formation of marketing management strategies in an industrial enterprise.

Presenting main material. Today, experts in the field of strategic management identify certain areas of its development in the field of marketing [19]:

- regular strategic management - a logical continuation of strategic planning, covering the subsystem of analysis and planning of the strategy and the subsystem of strategy implementation, i.e. management of strategic capabilities of the enterprise;

- real-time strategic management, which includes ensuring the solution of strategic tasks and problems that arise unexpectedly and require an immediate adequate response.

According to [21] G. Minzberg, B. Alstrend and J. Lempel systematize ten scientific schools of strategies and arrange them in a certain sequence (Fig. 1): based on the analysis of almost 1500 
articles formed ten major schools involved in strategy formation.

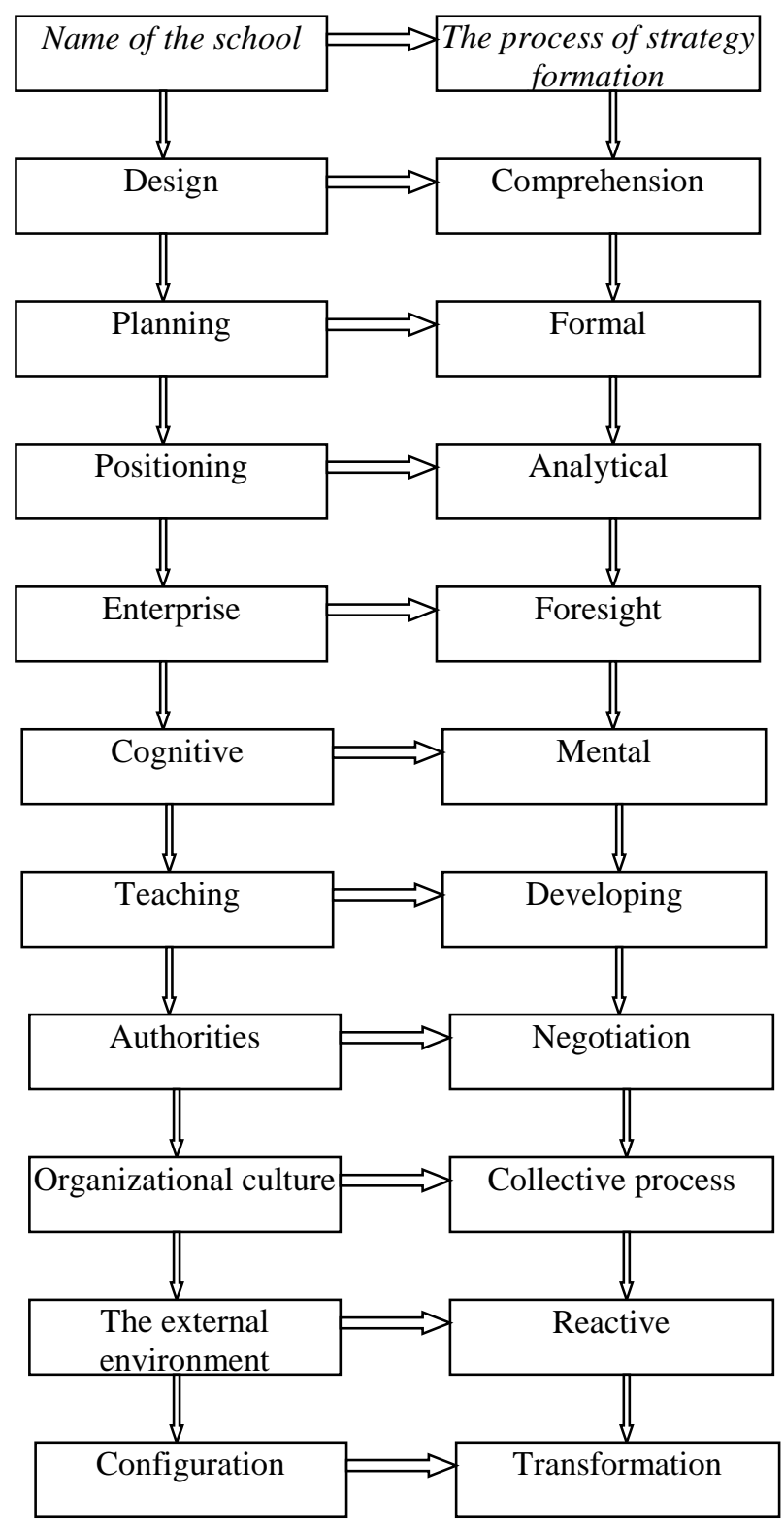

Fig. 1. Scientific schools of strategies Compiled by the author based on [20]

The first three schools bring together representatives who determine how the strategy should be formed, the followers of the next six try to determine how it is formed in practice. The tenth school brings together those who see strategy as volatile, depending on the circumstances.

To achieve the effectiveness of strategic management of marketing activities, it is advisable to use all possible tools provided by different schools: the experience of their own company and other companies, methods of forecasting and modeling, intuition and experience of top management.

According to leading experts in terms of marketing, the greatest contribution to the development of strategic management of marketing activities of enterprises belong to the school of positioning, the school of the environment and the school of configuration.

Representatives of the school of positioning use the basic ideas and concepts of strategic marketing management at the stage of creating a long-term business strategy, considering the company in the future, namely: by offering sustainable ways to create and differentiate competitive advantages, protected and adapted, capable of providing sustainable growth and act as the foundation of the strategy. Thus, such a school is a leader in the context of marketing strategic management and has a unique set of opportunities and techniques that can dramatically affect the propensity of strategic management as a science towards marketing.

It is well known that the opportunities and threats of the external environment together with the market potential of the industrial enterprise are a key factor in the formation of strategic management by influencing the marketing component of management. For the successful operation of any enterprise it is necessary to constantly monitor the external marketing environment, the absence of which will not allow you to effectively manage the company within a balanced system.

Examining the advantages and disadvantages of each of these schools, it was found that using the rules and methods of only one school is inappropriate given the complexity of enterprise development. Thus, the school of configuration, or transformation, which combines the principles of almost all studied schools of management, and also takes into account the time factor, acquires special significance. The time factor is taken into account on the basis of consideration of the enterprise from its position in the life cycle. The application of the methods of this school will provide an opportunity to create an adapted, flexible strategy and prerequisites for its implementation in a dynamic transformational environment.

According to the above, it is worth noting that strategic marketing management uses methods to develop an overall strategy, which is the basis of certain functional strategies (marketing, production, financial, human resources, 
innovation), and mechanisms for their implementation to achieve mission, goals and internal potential of the enterprise in a changing environment.

For further developed analysis of the methodology of strategic management of marketing activities of industrial enterprises, it is advisable to systematize and adapt the general principles of marketing management, as well as its basic functions.

The general principles of marketing strategic management include [22, p.41]:

- a clear idea of the strategic goals of the enterprise in the future;

- focusing on changes in the system of relationships with customers and partners;

- advanced management response to dangers and threats;

- focus on the development of sustainable competitive advantages;

- operational marketing to ensure the strategic development of the enterprise;

- taking into account the variability of the environment at the stage of forming a plan of strategic development of the enterprise;

- development of ways to achieve goals;

- drawing up a strategic marketing plan for three scenarios - pessimistic, optimistic and optimal;

- adaptability of marketing potential to changes in the external environment;

- focus of marketing potential on achieving strategic goals and their adjustment.

The main functions of marketing strategic management [23, p.37]:

- analysis of market opportunities, conducting marketing research;

- system of planning and marketing control;

- control over the implementation of annual plans;

- profitability control and strategic control;

- study of demand and market segmentation;

- selection of target segments and positioning of goods on the market;

- development of a marketing complex;

- building an organizational structure;

- marketing information system;

- development of a set of auxiliary marketing systems.

Thus, the role of marketing in strategic management is manifested at all levels of the hierarchy of enterprise management - general (corporate), business, functional and operational. Marketing plays a key role in several areas of strategic planning: first, it defines the concept that orients the company's strategy to address the needs of key customers, and second, it provides input to identify attractive market opportunities and assess the company's potential. Within each separate strategic branch of activity of the enterprise marketing helps to develop strategies of performance of tasks, acts as a methodological basis of strategic management.

The conducted careful multifaceted analysis of marketing activity of the researched enterprise is provided for development of directions of marketing strategy. To this end, first of all, it is advisable to form the mission and main purpose of marketing activities of the studied coal mining enterprise, the latter should be formulated at three levels: strategic, tactical and operational.

Before formulating the mission and objectives of the marketing activities of the coal enterprise as part of the process of forming a marketing management strategy, it is appropriate to identify the main stages of development and implementation of this strategy. These include:

I stage is the establishment of the mission of the coal mining enterprise, which is a fundamental tool for forming a long-term marketing strategy. The mission takes into account the main objectives of the coal mining company, as well as the structure of business units, features of technology. Taking into account the industry specifics of the researched enterprise and the subject of its activity defined in the charter with orientation on marketing as mission of marketing activity of the coal mining enterprise conquest of a worthy share of the coal market in the region is offered;

II stage - determining the goals of marketing activities of the coal enterprise at certain levels: strategic, tactical and operational. At the strategic level, it is necessary to establish the main goal of the marketing activities of the coal company to the selected mission and develop a tree of marketing goals.

As the main goal of marketing activities of the studied coal mining enterprise it is proposed to increase the level of competitiveness of the enterprise by increasing its sales.

In the future, the tactical goals of marketing activities of the enterprise and the operational goals necessary to achieve them are highlighted.

The tree of marketing goals of the coal mining enterprise SE "Mine" Central "SE" Krasnoarmiskugol "is shown in Fig.2. 
The mission of marketing activities of the coal company - to gain a decent share of the coal market in the region

The main purpose of marketing activities of a coal mining enterprise is to increase the level of competitiveness of the enterprise by increasing its sales

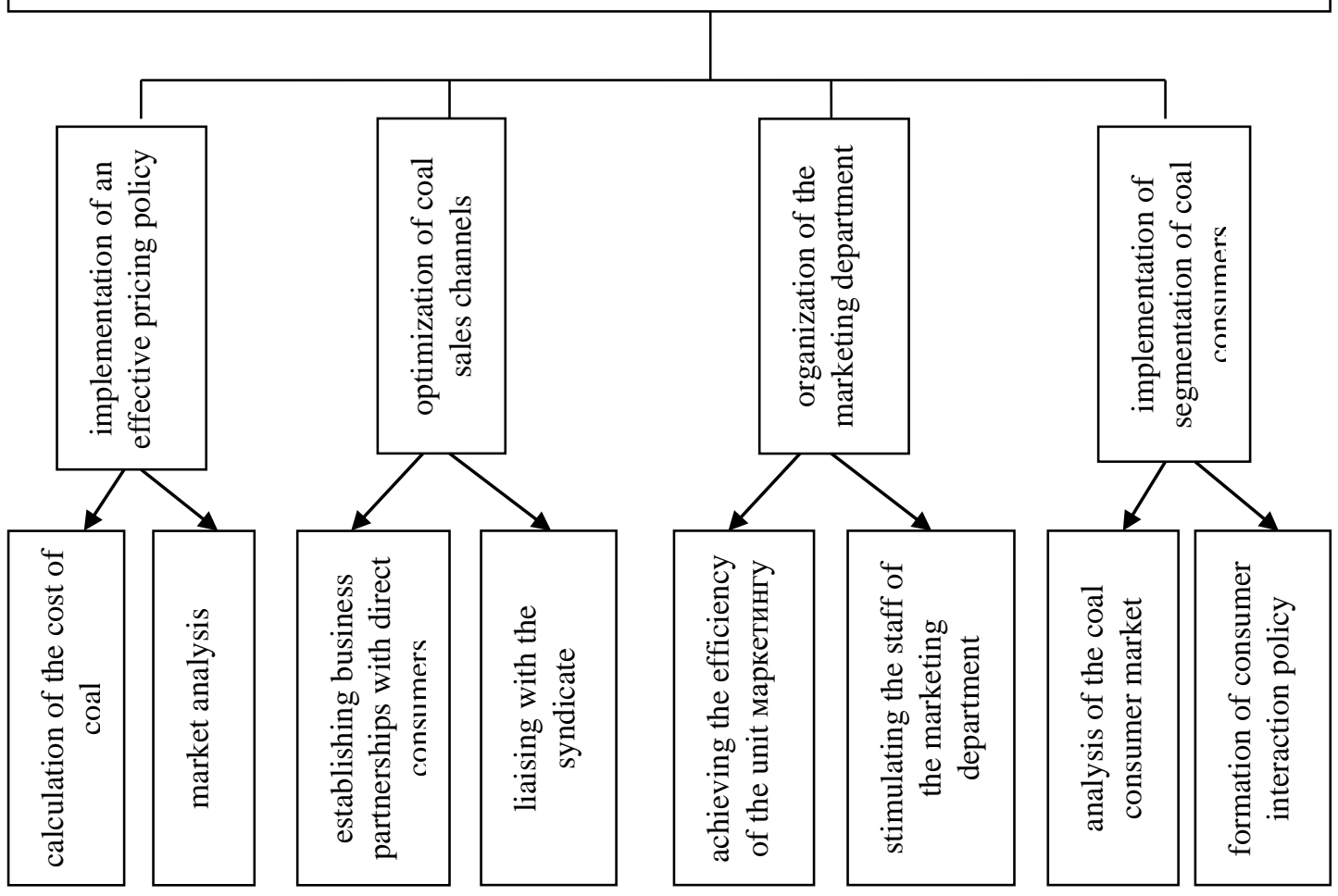

Fig. 2. "Tree of marketing goals" SE "Central Mine" SE "Krasnoarmeyskugol" Compiled by the author

The main purpose of production and economic activity of the coal mining enterprise is expedient first of all to provide performance of its main production function - maintenance of performance of tasks of the enterprise on coal mining with the smallest expenses. In order to ensure the fulfillment of the main goal of production activities, it is necessary to provide support for marketing activities in the form of timely and correct calculation of the cost of coal and analysis of market conditions.

The main purpose of production and economic activity of the coal mining enterprise is expedient first of all to provide performance of its main production function - maintenance of performance of tasks of the enterprise on coal mining with the smallest expenses. In order to ensure the fulfillment of the main goal of production activities, it is necessary to provide support for marketing activities in the form of timely and correct calculation of the cost of coal and analysis of market conditions.
Optimization of sales channels for coal products can be achieved by establishing business cooperation with direct consumers and establishing relationships with the coal syndicate. The organization of the marketing department is achieved by ensuring the effectiveness of the marketing department and the organization of an effective system of incentives for the staff of the marketing department. In order to segment coal consumers, the company must analyze the market of coal consumers and form a policy of interaction with consumers;

Optimization of sales channels for coal products can be achieved by establishing business cooperation with direct consumers and establishing relationships with the coal syndicate. The organization of the marketing department is achieved by ensuring the effectiveness of the marketing department and the organization of an effective system of incentives for the staff of the marketing department. In order to segment coal consumers, the company must analyze the market 
of coal consumers and form a policy of interaction with consumers;

III stage - analysis of the external environment of the coal mining enterprise, the study of the main factors influencing the formation of marketing strategy;

IV stage - analysis of the internal environment and SWOT-analysis of the marketing activities of the coal enterprise, diagnosis of its financial condition, inventory management system, competitive advantages of the enterprise.

On the basis of the collected quantitative and qualitative data, with the use of the information received at filling of the questionnaire and the analytical information the table of SWOT-analysis of marketing activity of mine is formed. In the process of analysis, first, the weaknesses and strengths in the marketing activities of the coal company, as well as its opportunities and threats.

Strengths:

- the presence of a process of constant renewal of fixed assets;

- availability and periodic renewal of highly qualified personnel;

- the established process of production and management of the enterprise;

- high level of technological development of the enterprise.

Weak sides:

- lack of working capital;

- weak provision of information technologies;

- restriction of the product market by one consumer;

- lack of an established system of cooperation under contracts;

- rapid reduction of marketing costs.

Features:

- increase in production due to already explored coal reserves at the field;

- reduction of costs for transportation of products due to reduction of railway tariffs;

- reduction of the tax burden;

- the presence of support for the coal industry by the state.

Threats:

- increasing the share of opencast mining;

- a steady downward trend in demand for products;

- dependence on the program of development of higher organizations;

- increase in payments for the use of natural resources;

- reduction of the number of employees in the industry;
- increased risk of accidents associated with methane emissions;

- insufficient level of wages in the industry.

Based on the SWOT-analysis of the marketing activities of the studied enterprise of the coal industry, the following conclusions are proposed:

- SIM field - the strategy of marketing activities is based on the use of the strengths of the enterprise in order to increase the probability and return on opportunities offered to it by the external environment;

- SLM field - marketing strategy uses the potential of opportunities to overcome the weaknesses identified at the coal enterprise;

- PPE field - logistics strategy aimed at eliminating the threats identified during the analysis through active use of strengths;

- SL field - marketing strategy is formed in order to rid the company of weaknesses and prevent threats.

The ratio of weaknesses and strengths of the enterprise, as well as its capabilities and threats is not constant, during the activities of the enterprise opportunities and threats may pass to each other, the strengths may become weak and vice versa. If the opportunity, common to all enterprises in the industry, was successfully used by competitors, it becomes a threat to the studied enterprise. And if the company is able to deflect the threat in any way, then new opportunities appear before it.

$\mathrm{V}$ stage - evaluation, justification and development of alternative strategies for marketing management and their varieties at different levels of management based on the established mission, goals and objectives, as well as the results of analysis of the external and internal environment of the enterprise.

Based on the analysis, it was found that at the highest level of strategic management as a corporate strategy, a market follower strategy is proposed, which is confirmed by the defined mission of the studied coal company and the considered "tree of marketing goals".

The strategy, focused on customer relations, determines the strategy of lower-level marketing activities - tactical strategy.

At the operational level, the strategy of managing the marketing activities of a coal mining enterprise is defined as a strategy of concentrated growth: a strategy to strengthen its market position $\rightarrow$ a strategy of horizontal marketing integration.

VI stage - building an organizational structure of marketing management in the enterprise, which depends on the effective 
implementation of the chosen strategy of marketing management and the enterprise as a whole. The studied enterprise of the coal industry is characterized by a linear-functional management structure - traditional or classical, based on the one hand on the linear powers, and on the other on the functional responsibilities.

Linear-functional management structures are built on the principle of functional departmentalization, which is based on the process of dividing the organization into separate elements, each of which has its own clearly defined, specific task and responsibilities. Specific characteristics and features of a particular unit correspond to the most important activities of the enterprise.

VII stage - the formation of the principles of implementation of the chosen management strategy of marketing activities, the implementation of the integration of management functions by its types.

Marketing control over the achievement of strategic goals of the coal mining enterprise SE "Central Mine" SE "Krasnoarmeyskugol" should be carried out on the basis of analysis of certain indicators in the dynamics:

- external evaluation indicators: growth rate of the coal market, capacity of the coal market, growth rate of competition;

- internal evaluation indicators: profitability of marketing activities, the company's share in the regional coal market, the level of contractual interaction with consumers.

When developing a content marketing strategy (consumer contract marketing) it is advisable to use the POST-method (People, Objectives, Strategy, Technology):

- People - analysis of existing or potential consumers and analysis of social media platforms used by them;

- Objectives - defining clear goals of marketing activities within the strategy of contractual interaction with consumers;

- Strategy (strategy) - the development of contractual relationships with consumers;

- Technology (technology) - selection of tools for social contacts.

Carrying out a thorough analysis of existing social media and their purpose, analysis of consumer preferences in their use.

To implement the development of content marketing strategy at the coal mining company, it is advisable to choose a strategy in the field of customer relations among the five main existing:

- the first - listening: research of what consumers say about the company's products;
- the second - statements: using social media to disseminate ads, ideas and opinions to consumers;

- the third - energy charging: search of clients and development of mutual relations of cooperation;

- fourth - support for contract consumers in the field of assistance to each other;

- fifth - attracting customers to work together to achieve marketing goals.

When substantiating customer relationship strategies, it is advisable to analyze the efficiency of the enterprise in the distribution and sales channels both in terms of transaction costs and internal costs arising from such activities, as well as to provide some flexibility in forming relationships with consumers. In this direction there is a problem of choosing the most appropriate form of contract that can provide the greatest savings in agency costs. The most effective way to reduce agency costs is to establish a more or less permanent partnership. However, agency costs are not decisive in the problem of minimizing transaction costs. They are eliminated in the process of forming partnerships.

As a result of building a system of business partnerships with consumers, the benefits of interaction between enterprise and consumers, related to the speed of response to external conditions, benefits in innovation, access to new markets, cost benefits from external synergies, risk reduction and system competence.

Table 1 shows a comparative description of the application of transactional marketing and partnership marketing in a coal mining enterprise.

For the successful implementation of longterm partnerships between suppliers and consumers, it is necessary to constantly monitor and develop a coherent marketing policy that ensures their sustainable nature. Therefore, in order to achieve the success of these relations, especially at a perilous level, it seems appropriate to identify among them the enterprise-integrator.

An integrator enterprise is an enterprise participating in a channel that has the greatest degree of influence over other participants, performs the functions of conducting environmental research and coordinating the actions of all participants in the channel in order to obtain additional benefits. As such an enterprise, it is advisable to choose the supplier - the investigated coal mining company, because it is able to assess the effectiveness of each participantconsumer of the supply and marketing channel on the basis of marketing partnerships. The 
mechanism for ensuring the implementation of these functions is through the provision of recommendations to each participant. In practice, the interaction of the supplier - the coal company and the consumer.

Table 1 - Comparative characteristics of the application of the coal mining company transactional marketing and marketing partnerships

\begin{tabular}{|c|c|}
\hline Transactional marketing & Partnership marketing \\
\hline \multicolumn{2}{|c|}{ Interaction costs } \\
\hline information retrieval costs & - the cost of maintaining the relationship \\
\hline - costs of negotiations & \\
\hline $\begin{array}{l}\text { - costs of monitoring compliance with the } \\
\text { terms of the contract }\end{array}$ & \\
\hline \multicolumn{2}{|c|}{ Risk and uncertainty } \\
\hline $\begin{array}{l}\text { Increasing uncertainty due to the constant search for } \\
\text { the most advantageous offer given the } 4 \mathrm{P} \text { - } \\
\text { increasing risk }\end{array}$ & $\begin{array}{l}\text { Uncertainty management due to the establishment } \\
\text { of long-term relationships - risk reduction }\end{array}$ \\
\hline \multicolumn{2}{|c|}{ Marketing orientation } \\
\hline $\begin{array}{l}\text { Single transactions using the concept of marketing } \\
\text { management }(4 \mathrm{P})\end{array}$ & $\begin{array}{l}\text { Long-term mutually beneficial relations due to } \\
\text { mutual loyalty and trust }\end{array}$ \\
\hline \multicolumn{2}{|c|}{ Time aspect } \\
\hline Short-term & Long-term \\
\hline \multicolumn{2}{|c|}{ Focus } \\
\hline Attracting new consumers, price & Consumer retention, relationships \\
\hline
\end{tabular}
Compiled by the author for [20]

An integrator enterprise is an enterprise participating in a channel that has the greatest degree of influence over other participants, performs the functions of conducting environmental research and coordinating the actions of all participants in the channel in order to obtain additional benefits. As such an enterprise, it is advisable to choose the supplier the investigated coal mining company, because it is able to assess the effectiveness of each participant-consumer of the supply and marketing channel on the basis of marketing partnerships. The mechanism for ensuring the implementation of these functions is through the provision of recommendations to each participant. In practice, the interaction of the supplier - the coal company and the consumer.

Coal takes different forms of marketing from one-time transactions to close cooperation, for the success of which it is necessary to choose a single coordinator for all parts of the interaction process, ensuring the production and consumption of coal, ie - with an integrator - a mine that can integrate physical and marketing channel. It is assumed that the cooperation of the integrator and other entities - consumers - is designed to improve the functioning of the entire supply and marketing channel on the basis of flexible partnership marketing, which will:
- to provide the general prospect and stability;

- assess the risks of mutual relations throughout the channel;

- specify the technical problems of the partnership;

- increase the flexibility of partnerships;

- specify the technical problems of the partnership;

- creation of necessary systems to order;

- coordination of benefits of partnersparticipants of the channel.

The enterprise-integrator must have a sufficiently high economic power in vertical partnerships to use the opportunities to ensure the implementation of the functions of the integrator.

The basis of effective partnerships is essentially the economic benefits of the participants, which can be determined by the producer-supplier / consumer of coal products using the analysis of the impact of marketing strategies on the internal environment of the enterprise. The initiative to form channels for the supply and sale of coal on the basis of the proposed marketing partnership should come from the marketing department of the coal company.

Discussion of results. The results of the study suggest that there is no guaranteed success in the application of marketing strategic 
management in isolation from the main activities of the industrial enterprise, therefore, the company using strategic management tools may fail due to errors in organization, motivation and control. However, a well-formed concept of marketing strategic management can form significant favorable factors for the effective functioning and development of an industrial enterprise.

Knowing what the company seeks to achieve helps to clarify the most appropriate ways of management. By making informed and systematic decisions, management reduces the risk of making the wrong decision due to erroneous or inaccurate information. Marketing strategic management helps to create the unity of the common goal within the enterprise. However, the measures proposed in the work to improve the marketing strategic management of an industrial enterprise on the example of a coal mining enterprise are not universal and need further development taking into account the specifics of a particular industry.

Conclusion. Based on the analysis of the definition of "strategic management" by various experts in the context of marketing activities of the enterprise, it is established that the latter is a necessary tool for its operation in terms of marketing orientation. Highlighted areas of strategic management in the field of marketing. The approaches of different scientific schools to the formation of concepts of strategic management of marketing activities are analyzed.

As directions of formation of strategy of management of marketing at the coal mining enterprise on the basis of the carried-out researches the following are offered: definition of mission, the purposes and tasks of marketing at all levels of management of marketing; substantiation of the strategy of partnership interaction.

The purpose of marketing activity of SE "Central" mine of SE "Krasnoarmeyskugol" is defined, its tasks and functions are specified. The stages of formation of marketing management strategy at the coal mining enterprise are offered. On the basis of the collected quantitative and qualitative data, with the use of the information received at filling in of the questionnaire and the analytical information the SWOT-analysis of marketing activity of mine is carried out.

It seems appropriate to offer a general sequence of interaction strategy for the use of the allocation of the enterprise-integrator as a sequence of stages of strategy planning in the channels of supply and marketing based on marketing partnerships.

The prospects of the research results are contained in the formation of the methodological and practical base for the improvement of strategic marketing planning, taking into account the specifics of the industry affiliation of industrial enterprises.

\section{List of references}

1. Ансофф И. Новая корпоративная стратегия / И.Ансофф. СПб.: ПИТЕР. - 1999. $416 \mathrm{c}$.

2. О. М. Ястремська. Стратегічне управління життєдіяльністю підприємств на основі інвестування для забезпечення гідної якості трудового життя /О. М. Ястремська, М.М.Мартиненко. [Електронний ресурс]. Режим доступу: http://repository.hneu.edu.ua/handle/123456789/2 1166).

3. Филиппова С.В. , Карпенко Л.М. Стратегічний конкурентний аналіз розвитку інноваційних підприємств: прогностична валідність. Актуальні проблеми економіки. 2016. №180. C. 392-404

4. Kuzmin O.E., Goryachka O.O. Management process of development of creative collectives at the enterprise. Institutionelle Grundlagen für die Funktionierung der $\ddot{O}$ konomik unter den Bedingungen der Transformation: Sammelwerk der wissenschaftlichen Artikel . Vol. 1 - Verlag SWG imex GmbH, Nürnberg, Deutschland, 2014. - PP. 224-226 ( РИНЦ , Übergeben für die Rezension, Conference Proceedings Citation Index - Social Sciences \& Humanities (CPCI-SSH), Thomson Reuters)

5. Могилевська О. Ю. Основні напрями вдосконалення методології маркетингового управління підприємствами машинобудування. Економіка та держава. 2012. № 3. С. 83-85. Режим доступу: http://nbuv.gov.ua/UJRN/ecde_2012_3_23.

6. Webster F.E. The changing role of marketing in the corporation. Journal of Marketing. 2012. 56. pp. 1-17.

7. Шемаєва Л. Г. Забезпечення економічної безпеки підприємства на основі управління стратегічною взаємодією із суб' єктами зовнішнього середовища. Управління проектами та розвиток виробництва. 2015. № 3. С. 19-33. Режим доступу:

http://nbuv.gov.ua/UJRN/Uprv_2015_3_5.

8. Ареф'єва О.В. Управління змінами на підприємстві: оцінка доцільності процесу в організаційному та економічному аспекті. 
Стійкий розвиток в умовах соиіально орієнтованої економіки. Монографія / за ред. Прохорової В.В. Харків, Смугаста типографія. 2016. C. 163-171.

9. Гриньова В. М. Процес підготовки реструктуризації підприємств машинобудування : організація управління: монографія. Харків, вид-во ХНЕУ. 2010. 238 с.

10. Фатхутдинов P. А. Управление конкурентоспособностью организации. М.: ЗАО «Бизнес-школа "Интел-Синтез», 2005. $544 \mathrm{c}$.

11. Jensen M., Meckling W. Theory of the Firm: Managerial Behavior, Agency Costs and Ownership Structure. Journal of Financial Economics. 2016. №3. pp. 305-360.

12. Хміль Ф. І. Економічні та суспільні зміни та їх вплив на управління вітчизняними підприємницькими організаціями. Торгівля, комериія, підприємництво. 2011. Вип. 12. С. 9-11. Режим доступу: http://nbuv.gov.ua/UJRN/Torg_2011_12_4.

13. Швандина А.А. Адаптация организационных структур управления к современным рыночным условиям. Вісник СумДУ. Серія «Економіка». 2008. № 1. С. 2025.

14. Petrovich Y.O. Innovation process management in Ukraine: problems in comercialization of scientific and technical developments: The monograph. Lviv: Lviv Polytechnik National University. 2018. P. $168-$ 182.

15. Управління підприємствами: сучасні тенденції розвитку: монографія: за заг. ред. проф. О. С. Федоніна. К. : КНЕУ. 2006. 288 с.

16. Верба В. А. Концептуальні положення оцінювання управлінського консультування. Ефективна економіка. 2012. № 1.1 Режим доступу: http://nbuv.gov.ua/UJRN/efek_2012_1_12.

17. Hakansson H. International Marketing and Purchasing of Industrial Goods. H. New York: John Wiley \& Sons Editor, 2011. 124 p.

18. Федорова Н.Н. Организационная структура управления предприятием. М.: ТК Велби. 2011. $256 \mathrm{c.}$

19. Бідняк М.Н. Організація управління. К.: А.С.К. 2013. 176 с.

20. Шершнева 3. Е., Оборская С. В. Стратегическое управление. К.: КНЭУ. 2009. $384 \mathrm{c}$.

21. Минцберг Г. , Альстрэнд Б., Лэмпел Д. Школы стратегий: стратегическое сафари: экскурсия по дебрям стратегий [пер. с англ. Д.
Раевская, Л. Дарук]. СПб.: Питер. 2008. 445 c.

22. Hakansson H., Ford D. How Should Companies Interact in Business networks? Journal of Business Research. 2010. 5. P.56-54

23. Ford D. Understanding Business Marketing (3rd ed.). High Holborn, London: Thomson Learning. 2012. 585 p.

\section{References}

1. Ansoff, I. (1999). New corporate strategy, ST. PETERSBURG, 416 p. [in Russian].

2. Yastremskaya, O. M. and Martynenko, M. M. (2012). Strategic management of life of enterprises on the basis of investment to ensure a decent quality of working life. [online]. Retrieved from:

http://repository.hneu.edu.ua/handle/123456789/2 1166 [in Ukrainaian].

3. Filippova, S.V. and Karpenko, L. M. Strategic competitive analysis of the development of innovative enterprises: prognostic validity (2016). Current economic problems, 180, 392404 [in Ukrainaian].

4 Kuzmin, O.E. and Goryachka, O. O. (2014). Management process of development of creative collectives at the enterprise Institutionelle Grundlagen für die Funktionierung der Ö konomik unter den Bedingungen der Transformation: Sammelwerk der wissenschaftlichen Artikel, 1, 224-226. Verlag SWG imex GmbH, Nürnberg, Deutschland (РИНЦ, Übergeben für die Rezension, Conference Proceedings Citation Index - Social Sciences \& Humanities (CPCI-SSH), Thomson Reuters) [in English].

5. Mogilevsky, O.Yu. (2012). The main directions of improving the methodology of marketing management of machine-building enterprises. Economy and state, 3, 83-85 [in Ukrainaian].

6. Webster, F.E. (2012). The changing role of marketing in the corporation. Journal of Marketing 56, 1-17 [in English].

7. Shemayeva L.G. (2015). Categorical apparatus of management of strategic interaction of the enterprise and subjects of external environment. Project management and production development, 3, 19-33 [online]. Retrieved from: http://nbuv.gov.ua/UJRN/Uprv_2015_3_5.

[in Ukrainaian].

8. Aref'eva, A. (2015). Change management in the enterprise: assessment of the feasibility of 
the process in organizational and economic aspects. Sustainable development in a socially oriented economy. Monograph Kharkiv: Striped typography, P. 163-171 [in Ukrainaian].

9. Grinyova, V.M. and Novikov, N.V. (2010). The process of preparation for the restructuring of machine-building enterprises: the organization of management. Kharkiv: KhNEU Publishing House, 238 p. [in Ukrainaian].

10. Fathutdynov, R.A. (2005). Management of competitiveness of the organization. Moscow: ZAO Business School Intel-Sintez, 544 p. [in Russian].

11. Jensen, M. and Meckling, W. (2016)/ Theory of the Firm: Managerial Behavior, Agency Costs and Ownership Structure/ Journal of Financial Economics, 3, 305-360 [in English].

12. Khmil', F.I. (2011). Economic and social changes and their impact on the management of domestic business organizations. Trade, commerce, entrepreneurship, 12, 9 -11 [online]. Retrieved from: http://nbuv.gov.ua/UJRN/Torg_2011_12_4 [in Ukrainaian].

13. Shvandina, A.A. (2008). Adaptation of organizational structures of management to modern market conditions. Bulletin of SSU. Economics Series, 1, p. 20-25. [in Russian].

14. Petrovich, Y.O. (2018). Innovation process management in Ukraine: problems in comercialization of scientific and technical developments: The monograph. Lviv Polytechnik National University. Lviv. P. $168-182$ [in English].

15. Goncharova, N. P. and Fedonin, O.S. and Shvydanenko, G. O. (2006). Enterprise management: current trends: monograph. Kyiv: KNEU, 288 p. [in Ukrainaian].

16. Verba, V.A. (2012). Conceptual provisions for the evaluation of management consulting. Efficient economy, 1 [online]. Retrieved from: http://nbuv.gov.ua/UJRN/efek_2012_1_12. [in Ukrainaian].

17. Hakansson, H. (2011). International Marketing and Purchasing of Industrial Goods / New York: John Wiley \& Sons Editor, 124 p. [in English].

18. Fedorova, N.N. (2011). Organizational structure of enterprise management. Moscow: TC Welby, 256 p. . [in Russian].

19. Bidnyak, V. M. (2013). Management organization. Kyiv: A.S.K., 176 p. [in Ukrainaian].

20. Shershneva, Z.E. and Oborskaya, S.V. (2009). Strategic management. Kyiv: KNEU, 384 p. [in Ukrainaian].

21. Mintzberg, G.and Alstrend, B. and Lampel, D. (2008). Schools of strategies: strategic safari: a tour of the wilds of strategies, [trans. with English D. Raevskaya, L. Daruk]. SPb .: Peter, 445 p. [in Russian].

22. Hakansson, H. and Ford, D. (2010). How Should Companies Interact in Business networks? Journal of Business Research, P.56-64 [in English].

23. Ford, D. (2012). Understanding Business Marketing (3rd ed.). High Holborn, London: Thomson Learning, p. 585 [in English].

Надійшла до редакиії 17.09.2019p.

Мізіна Олена Вікторівна - к.е.н., доц., доцент кафедри управління та фінансово-економічної безпеки, ДВНЗ "Донецький національний технічний університет",

E-mail: olena.mizina@donntu.edu.ua

Амельницька Олена Володимирівнаа - к.е.н., доц., доцент кафедри транспортного менеджменту

і логістики,

ДВНЗ "Приазовський державний технічний університет",

E-mail: olena.amelnytska@gmail.com

Амельницька Марія Іванівна - здобувач спеціальності 072 «Фінанси, банківська справа

та страхування»,

ДВНЗ "Донецький національний технічний університет",

E-mail: mamelnitskaya00@gmail.com 


\section{ВДОСКОНАЛЕННЯ МАРКЕТИНГОВОГО СТРАТЕГІЧНОГО УПРАВЛІННЯ НА ПРОМИСЛОВОМУ ПІДПРИЕМСТВІ}

Розвиток теоретичних основ та розробка методичних рекомендацій щзодо формування та удосконалення стратегій управління маркетингом на промислових підприємствах з урахуванням специфіки їх галузевої приналежності. Дослідження сутності та складових стратегічного управління маркетингом базується на методах системного аналізу і сінтезу. Аналіз етапів формування стратегічного управління маркетингом на промисловому підприємстві здійснено на основі структурно-логічних методів. Проаналізовано підходи різних наукових шкіл щцодо формування концепџій стратегічного управління маркетинговою діяльністю. 3'ясовано, щзо стратегічне управління маркетинговою діяльністю використовує методи розробки загальної стратегії, щчо є основою певних функиіональних стратегій (маркетингової, виробничої, фінансової, кадрової, інноваційної), та механізми їх реалізації з метою досягнення відповідності місії, иілей та внутрішнього потенціалом підприсмства умовам мінливого зовнішнього середовища. Обтрунтовано напрями формування стратегї управління маркетингом на вугледобувному підприємстві на основі проведених досліджень: визначення місії, иілей та завдань маркетингу на всіх рівнях управління маркетингом; обтрунтування стратегії партнерських відносин взаємодіі. Запропоновано етапи формування стратегї управління маркетингом на підприємстві вуглевидобутку. На основі зібраних кількісних $i$ якісних даних, 3 використанням інформації, отриманої при заповненні анкети і аналітичної інформації здійснено SWOT-аналіз маркетингової діяльності шахти. На основі узагальнення здісненого аналізу уявляється доиільним запропонувати загальну послідовність формування стратегії взаємодії з використанням виділення підприємства-інтегратора як послідовність етапів планування стратегї в каналах забезпечення та збуту на базі маркетингу партнерських відносин. Обтрунтовано етапи формування стратегії управління маркетингом на промисловому підприємстві з урахуванням специфіки його галузевої приналежності та стратегії взаємодії на основі виділення підприємства-інтегратора та формування маркетингу партнерських відносин..

Отримані результати дослідження визначають загальні напрями удосконалення маркетингового стратегічного управління на промисловому підприємстві иляхом визначення етапів формування стратегії маркетингу та маркетингу партнерських відносин.

Ключові слова: стратегія маркетингу, управління маркетингом, принципи маркетингового управління, функиії маркетингового стратегічного управління, вугледобувне підприємство, корпоративна стратегія. портфельна стратегія, SWOT-аналіз, портфель партнерства

Мізіна Олена Вікторівна - к.е.н., доц., доцент кафедри управління та фінансово-економічної безпеки, ДВНЗ "Донецький національний технічний університет",

E-mail olena.mizina@donntu.edu.ua

Амельницька Олена Володимирівна - к.е.н., доц., доцент кафедри транспортного менеджменту і логістики,

ДВНЗ "Приазовський державний технічний університет",

E-mail: olena.amelnytska@gmail.com

Амельницька Марія Іванівна - здобувач спеціальності 072 «Фінанси, банківська спрва

та страхування»,

ДВНЗ "Донецький національний технічний університет",

E-mail: mamelnitskaya00@gmail.com

\section{СОВЕРШЕНСТВОВАНИЕ МАРКЕТИНГОВОГО СТРАТЕГИЧЕСКОГО УПРАВЛЕНИЯ НА ПРОМЫШЛЕННОМ ПРЕДПРИЯТИИ}

Цель - развитие теоретических основ и разработка методических рекомендаций по формированию и совершенствованию стратегий управления маркетингом на промышленных предприятиях с учетом специфики их отраслевой принадлежности. Исследование сущности и составляюших стратегического управления маркетингом базируется на методах системного анализа и синтезу. Анализ этапов формирования стратегического управления маркетингом на промышленном предприятии осуществлен на основе структурно-логических методов. Проанализированы подходы различных научных школ по формированию кониепций стратегического управления маркетинговой деятельностью. Выяснено, что стратегическое управление маркетинговой деятельностью использует методы разработки общей стратегии, является основой определенных функииональных стратегий (маркетинговой, производственной, финансовой, кадровой, инновационной) и механизмы их реализации с ичелью достижения соответствия миссии, ичелей и внутреннего потенциалом предприятия условиям меняющегося внешней среды. Обоснованы направления формирования стратегии управления маркетингом на угледобывающем предприятии на основе проведенных исследований: 
определение миссии, целей и задач маркетинга на всех уровнях управления маркетингом; обоснование стратегии партнерских отношений взаимодействия. Предложено этапь формирования стратегии управления маркетингом на предприятии угледобычи. На основе собранных количественных и качественных данных, с использованием информаџии, полученной при заполнении анкеты и аналитической информации осуществлено SWOT-анализ маркетинговой деятельности шахты. На основе обобщения предпринята анализа представляется иелесообразным предложить общую последовательность формирования стратегии взаимодействия с использованием выделения предприятия-интегратора как последовательность этапов планирования стратегии в каналах обеспечения и сбыта на базе маркетинга партнерских отношений. Обосновано этапы формирования стратегии управления маркетингом на промышленном предприятии с учетом специфики его отраслевой принадлежности и стратегии взаимодействия на основе выделения предприятия-интегратора и формирования маркетинга партнерских отнотений.. Полученные результатьл исследования определяют общче направления совершенствования маркетингового стратегического управления на промышленном предприятии путем определения этапов формирования стратегии маркетинга и маркетинга партнерских отношений.

Ключевые слова: стратегия маркетинга, управления маркетингом, приниипь маркетингового управления, функиии маркетингового стратегического управления, угледобывающее предприятие, корпоративная стратегия. портфельная стратегия, SWOT-анализ, портфель партнерства

Мизина Елена Викторовна - к.э.н., доц., доцент кафедры управления и финансово-экономической безопасности, ДВНЗ "Донецкий национальный технический университет",

E-mail olena.mizina@donntu.edu.ua

Амельницька Елена Володимиривна - к.э.н., доц., Доцент кафедры транспортного менеджмента и логистики, ДВНЗ "Приазовский государственный технический университет",

E-mail: olena.amelnytska@gmail.com

Амельницька Мария Ивановна - соискатель специальности 072 «Финансы, банковское дело и страхование», ДВНЗ "Донецкий национальный технический университет",

E-mail: mamelnitskaya00@gmail.com 